KAZIMIERZ KRZAKIEWICZ SZYMON CYFERT

\title{
The Strategic Dimension of the Dynamic Capabilities of Enterprises'
}

Professor Kazimierz Krzakiewicz Poznań University of Economics Professor Szymon Cyfert Poznań University of Economics

\section{Introduction}

Strategic management is a science of changes. When proving the correctness of the foregoing statement, one could point out the dynamic nature of the issues investigated by strategic management, the pace of change in the business environment, and the high variability of the sources of competitive advantage. As a consequence of the drastic changes in the economic environment, the approach to competition and the mechanisms employed by companies, taking place on the turn of the 21st century, conclusions highlighting the emerging crisis and the twilight of the theory of strategic management have been formulated. While it is possible to point out certain factors which deny the validity of the conclusions declaring "the twilight of strategic management", the validity of the postulates pointing out the need to put the previous approaches to strategic management in order and to develop new paradigms cannot be easily undermined.

1 The project was founded by The National Science Centre in Poland allocated on the basis of a decision DEC-2013/11/B/HS4/00697. 
In an attempt to propose new paradigms of strategic management the objective of article has been done to contribute to the debate on the concept of dynamic capabilities of enterprises and present of its principles from the perspective of strategic management

\section{Paradigms in strategic management}

Strategic management, just like the entire field of management sciences, is subject to the process of change, which results in the emergence of new paradigms and the decline of those which have been undermined. The complexity of the processes of change calls for simplification, collation and structuring, i.e. for searching for certain laws and principles. On the other hand, the dynamics of the environment is an incentive to aggravate disorder through continuous experiments and transfer of experience from other scientific fields, up to a point where, through increasing disorder, the highest level of order, i.e. chaos, is achieved.

A critical analysis of the attempts to formulate new paradigms of strategic management, carried out over the past several years, leads to two general conclusions. First of all, we can observe a relatively low effectiveness of the actions aimed and building new paradigms constituting the basis for diagnosing and analyzing the logic behind the strategic actions taken in organizations, which is indicative of the postulative rather than normative nature of such actions. Second of all, a thesis may be formulated that the concept which best meets the requirements to be met by paradigms is the concept of dynamic capabilities, reflecting the shift from the classical approach to the entrepreneurial activities ensuring a relative durability of competitive advantage, typical of a knowledgebased economy.

The assumptions of the concept of dynamic capabilities, developed in the late 80 's and early 90's of the 20th century, can be considered to be ahead of the recommendations formulated in the 90's of the 20th century, highlighting the value of developing a "dynamic theory of strategic management" (Porter 1991, Spender 1996, Markides 1999). In recent years, the concept of dynamic capabilities, appreciating the significance of the organizational ability to identify in advance and seize new business opportunities as a source of permanent competitive advantages, has clearly strengthened its position in the "world of strategic management". The correctness of the logic behind the concept of dynamic capabilities is reflected in the assumptions of the concepts created at the beginning of the 21st century, such as the concept of "strategic 
flexibility" (Volberda 2008) or the concept of "everlasting organizations" (Collins, Porras 2008).

\section{The concept of dynamic capabilities}

Dynamic capabilities constitute an important theoretical construct useful for the purpose of understanding the phenomenon of competition under the new global circumstances. First and foremost, dynamic capabilities are different from operational capabilities in that they stress the processes of change management. In the literature on the subject it is most often pointed out that dynamic capabilities constitute a company's potential when it comes to integrating, creating and reconfiguring internal and external competencies in order to ensure compatibility with the ever-changing conditions of the environment (Teece, 2008). K. Eisenhardt and J. Martin (2010, p. 1107)see dynamic capabilities as inter-organizational processes of integrating, reconfiguring and obtaining resources or disposing of them in order to ensure consistency with the changes in the market or to generate such changes.

The "dynamic resource concept" is an approach based on the assumptions of dynamic capabilities, which constitutes an attempt to add new content to the traditional resource approach and which highlights the value of analyzing all the organizational capabilities and not just the "dynamic capabilities". Crucial for this concept is the assumption that even though some capabilities may be centered around the processes of adaptation, learning and change, all capabilities have a potential for introducing changes (Helfat, Peteraf 2003, p. 998). The dynamic resource concept supports the idea of "capability lifecycle", which consists of four stages: creation, development, maturity, and, once maturity has been achieved, it is assumed that one of the following 6 stages may ensue: decline, limitation of expenditure on a given capability, renewal, replication, redistribution or recombination. The assumptions of the dynamic resource concept make it possible to explain the differences between organizations when it comes to organizational capabilities. One should keep in mind, however, that this concept suffers from significant methodological constraints. For the dynamic resource concept adopts the assumptions of the traditional resource approach (based on the mechanisms of effectiveness of allocation), which it attempts to strengthen by adopting some assumptions of the evolutionary theory. Moreover, despite emphasizing the role of managers in creating "new combinations" in the capability lifecycle, the dynamic resource concept only partially takes into consideration the significance of

9

KAZIMIERZ KRZAKIEWICZ

SZYMON CYFERT 
the entrepreneurship factor. Thus, it overlooks the issue of identifying new business opportunities and the need of change through a proactive analysis of new markets, new technologies and competitive risks.

There are three issues critical for the concept of dynamic capabilities: the degree of capability dynamics, the role of the anticipatory actions of managers and the impact of the environment on the shaping of dynamic capabilities. Three approaches to defining the aforesaid issues and viewing dynamic capabilities are highlighted in the literature on the subject.

In the first approach, based on the premises of the evolutionary theory and the concept of strategy founded on classical microeconomic logic, it is assumed that capability dynamics has a limited impact on a company's success and that the role of managers in this process is also limited. According to the assumptions of the theory of population ecology and the theory of evolution, in the course of their development, organizations make habits and create sets of routine behaviors which not only constitute the main cause of organizational inertia but also disorganize the process of shaping new behavior models. Moreover, the process of renewal of capabilities is hampered by: the historical trajectory of a company's development, the complementary assets (the development of new technologies or new markets can reduce their value) and the "windows of opportunity" (if an organization fails to adjust its potential to the emerging technologies and markets, doing so at a later time may be difficult or - in extreme cases - impossible). It should be noted that the historical trajectory of development and the complementary assets constitute important elements of the concept of dynamic capabilities, which embeds them in the methodological grounds other than the traditionally-defined ones.

In the second approach, managers are believed to play the key role in creating dynamic capabilities. At the same time it is assumed that there is a link between the pace and nature of changes and the turbulence and dynamics of the environment. In a "moderately turbulent" environment changes occurs relatively often, are predictable, and are linear, as a result of which dynamic capabilities may be regarded in terms of routine behaviors. In a "turbulent" environment, capabilities take the form of simple, experimental and dynamic processes. In other words, the mechanism of learning, influenced by the dynamics and changeability of the environment, lies at the heart of the evolution of dynamic capabilities. Therefore, the literature on the subject emphasizes that the concept of dynamic capabilities helps to explain the phenomena occurring in the sectors characterized by fast technological change. Based on this assumption, H. Mintzberg (1994) criticized the school of strategic planning, pointing out 
that "analysis" (i.e. the methodology of strategic planning) should be reserved to the process of managing organizations in a relatively stable environment, while "synthesis" (i.e. strategic management) should be used in a dynamic and turbulent environment.

Having analyzed the phenomenon of competition in a dynamic environment, K. Eisenhardt and J. Martin (2010) noted that problems with supporting dynamic capabilities result from improvisation in the management process, since such capabilities are not "memorized", which means that external threats to the durability of competitive advantage are complemented by internal threats. Basing their theory on the foregoing observation and assuming that different kinds of dynamic capabilities may be corresponding (the phenomenon of "the best management practices"), K. Eisenhardt and J. Martin presented a mechanism for building competitive advantages different from the one described in the mainstream concept of dynamic capabilities (Teece 2008). Assuming that it is impossible for a company to secure a sustainable advantage in dynamic sectors, K. Eisenhardt and J. Martin remark that dynamic capabilities are valuable from the point of view of gaining competitive advantage due to the possibility to configure resources, which means that this value is not directly connected with the capabilities themselves. Therefore, dynamic capabilities are an indispensable but insufficient condition for gaining competitive advantage. Moreover K. Eisenhardt and J. Martin maintain that the concept of dynamic capabilities should not be presented in terms of a separate paradigm of the theory of strategic management.

The third approach, referring to the original premises of the concept of dynamic capabilities (Teece, 2008), assumes that the effectiveness of using dynamic capabilities depends on the level of development of an organization's meta-capabilities, being a conglomerate of two interrelated factors: the ability to identify new business opportunities and the ability to use them effectively.

As opposed to the approaches described above, D. Teese's proposal is based on a combination of the idea of "asymmetrical" advantage and organizational adaptation to change, and on the synthesis of the concepts of organizational learning, leadership, entrepreneurship and the economic theories of the firm. The fundamental assumption of D. Teese's theory is that ensuring the effectiveness of the organizational learning processes is a critical condition for gaining and maintaining competitive advantage (Zollo, Winter 2002), which means that the degree of utilization of dynamic capabilities is not determined by the dynamics and turbulence of the environment. However, the foregoing assumption does not mean that organizations should be in a permanent state of change, which,

11

KAZIMIERZ KRZAKIEWICZ

SZYMON CYFERT 
in the long run, would result in internal chaos. What is more, not all organization's reactions to innovation and change should be seen as dynamic capabilities (Winter 2003).

Moreover, it is emphasized that only the processes of shaping external and internal competencies of an organization within the scope of creating new combinations of assets, which are difficult to replicate, can constitute a source of competitive advantage (Teece, 2008). Such dynamic capabilities cannot be bought on the market - they can only be shaped as new capabilities or configured from the existing ones. Managers and their entrepreneurial behaviors are believed to play a crucial role in the process of shaping dynamic capabilities. D. J. Teece classifies four organizational capabilities as dynamic capabilities:

- designing effective innovation and change management processes,

- intuition and vision indispensable for creating new business models,

- shaping mechanisms for effective investment decision-making,

- effective management of transactions.

In his concept, D. Teece presents the mechanism for building and utilizing dynamic capabilities in the following way. An organization, utilizing the resources available on the market, through integration processes turns them into appropriate combinations which constitute the source of unique competencies. At the same time, striving to ensure a stable demand for the offered products/services in a continuously changing business environment, an organization must have numerous capabilities at its disposal, which will allow it to identify new business opportunities and risks, and the benefits related thereto. Therefore, ensuring a long-term competitive advantage based on dynamic capabilities comes down to being able to utilize such capabilities faster and more effectively that one's competitors, who are also trying to create combinations of resources ensuring that kind of advantage. In other words, when trying to generate value on the basis of the dynamic capabilities at its disposal, an organization must adapt faster and more effectively to the business environment than its competitors, which means that in creating competitive advantage, the focus lies on the response time, compared with the behaviors of competitors.

\section{Dynamic capabilities and competitive advantage}

There is an obvious link between dynamic capabilities and the results of a company's business activity. Dynamic capabilities make it possible to shape and modify competencies, operational behaviors and resources of a company 
(in order to boost their effectiveness), which, in turn, determine the results of its business activity and its market position. It should be noted that even though the dynamic capabilities of different companies may be corresponding, they will have a different impact on the business due to the differences in the expenditure on maintaining such capabilities and different periods of their utilization (Zott 2008).

In order to build and maintain dynamic capabilities, learning mechanisms must be incorporated into the management system of an organization and appropriate organizational forms must be ensured. M. Zollo and S.G. Winter (2002, p. 340) argue that dynamic capabilities are the result of organizational learning and fixed methods of collective activity, through which an organization regularly generates and modifies its operational behaviors in a way which increases its effectiveness. M. Zollo and S.G. classify gaining experience, creating knowledge and codifying knowledge as learning mechanisms. In the literature on the subject it is highlighted that organizational structures of the companies utilizing the concept of dynamic capabilities should be characterized by a high degree of decentralization, ensuring flexibility and allowing companies to react fast to the changes in the environment. Such a view has been expressed by H. Volberda, who maintains that dynamic capabilities are connected with the adhocratic structure as presented by H.Mintzberg or with the organic structure (Volberda, Elfring 2010).

Highlighting the correctness of the assumptions of the concept of dynamic capabilities, one could refer to its "analytical advantages" resulting from the "managerial extension" of the economic theory of the firm and from "breaking" the dichotomy of the theory of strategic management through promoting the concept of organizational learning.

\section{Strategic aspects of the concept of dynamic capabilities of enterprises}

The managerial extension of the economic theory of the firm within the concept of dynamic capabilities is close to the "strategic theory of the firm" (Rumlet 1984), according to which in modern economy emphasis should be put on identifying new business opportunities and using them for ensuring competitive advantage rather than on strategic behaviors. As a result of taking the foregoing view, the issues of entrepreneurship and leadership come to the fore of the theory of the firm.

While in the classical microeconomic approach the optimum of managerial decisions is determined using the profit maximization criterion, in the 
concept of dynamic capabilities it is assumed that - in accordance with the premises of the evolutionary theory - managerial decisions determine routine behaviors.

The concept of dynamic capabilities reflects the diverse nature of strategic management and is coupled with the theory of the firm in a productive way. On the one hand, the development of the concept of dynamic capabilities can be seen as a constituent of the process of strengthening economic logic in the theory of organization and management. On the other hand, the concept of dynamic capabilities facilitates the penetration of the issues of leadership, organizational culture and other organizational aspects of company operation into the sphere of interest of the economic theory of the firm.

An analysis of the literature and of the assumptions of the concept of dynamic capabilities yields four premises validating the creation of a new paradigm of the theory of strategic management, while referring to the concept of dynamic capabilities. The first premise pertains to the behavior of the members of an organization. In analyzing the behavior of different groups in the process of organization management, the theory of strategic management highlights the purposefulness of taking into account the broad and realistic depiction of the decision-making process, integrating both the rational analysis of the problem (which is typical of the theory of economy) and the limitation of rationality (taken into account in behavioral sciences). The second premise pertains to the nature of an organization. As a result of adopting a systematic approach to the analysis of organizations and contemplating organizations in terms of a social system, human resources become a critical component of an organization. This makes it necessary to take into consideration such issues as: imperfection of incentive systems, imperfection of management models, bureaucratization of decisionmaking processes, etc., in the process of designing and managing an organization. Moreover, it is important to include into the analysis of an organization the field of knowledge which cannot be easily gained or "done away with". The third premise concerns the impact of an organization on its environment. According to the assumptions of the modern theory of strategic management, the relations between an organization and its business environment are based on the idea of feedback, which means that an organization being under the influence of the variables coming from the environment can and should shape its environment. The fourth premise pertains to entrepreneurship. Entrepreneurs set up new organizations, initiate the creation of new markets and the introduction of technological change. However, the creation of new organizations and the emergence of new markets and technologies is not only the result of changes in 
the customer expectations but also in the motives and preferences and of new business opportunities. Entrepreneurship and innovations are connected with creating new combinations of production factors, as a result of which ensuring the right balance between the creation of the new and development of the existing constitutes one of the major problems of strategic management.

It should be emphasized that, as opposed to M. Porter's (1996) view, according to which routine behaviors cannot be a source of competitive advantage, the concept of dynamic capabilities allows for such a possibility on condition that such behaviors are unique (as a part of a unique business model) and that the impermanence of such advantages is accepted.

Apart from the proposal to adopt a new approach to the analysis of the relations and balance between the entrepreneurial and administrative factors contributing to company development, the concept of dynamic capabilities significantly contributes to eliminating the dichotomy of the theory of strategic management. What is emphasized in the concept of dynamic capabilities is the importance of adaptation in the processes of ensuring an entrepreneurial economic rent, which is a reference to the critical dilemma in the process of change management. Thus, the limitations of the analysis of change management typical of the traditional theory of the firm (which does not appreciate the issue of change) and of the theory of organization (which does not pay enough attention to changes) are partially weakened (Volberda, Elfring 2010).

An analysis of the literature leads to a conclusion that further development of strategic management is going to be contingent on the assumptions and postulates developed within the framework of the concept of dynamic capabilities and related to the internal and external aspects of an organization's operation, ensuring a high level of inter-organizational integration and external competitive dynamics. The approach which argues that the relationship between adaptation at the company level and selection of companies under the influence of external forces should be taken into account, is consistent with the thesis which is currently valid in the modern theory of strategic management, according to which adaptation and selection are not opposing phenomena, but are closely interrelated (Volberdo, Elfing, 2010, p. 265). As such, the concept of dynamic capabilities is closely related to the concepts of co-evolution (of a company and its environment) and ecosystem. Striving for co-evolution in a situation where organizations effectively develop unique capabilities and competitive advantages, which quickly perish as a result of the growing external competitive dynamics, could bring about negative consequences. Unfortunately, such phenomena are hardly ever analyzed in-depth in the process of designing 
company strategies. Therefore, the need to exchange the old paradigm, favoring the "first survival than development" sequence of events, for a new one "survival through development", is postulated.

\section{Conclusions}

Despite the acceptance of the concept of dynamic capabilities expressed in the literature and it being treated as "the most forward-thinking school of strategic management", many researchers are skeptical about the essence of the concept of "dynamic capabilities", its applicability (Winter 2003) and scientific status. For instance, H. Mintzberg treats the concept of dynamic capabilities as a constituent of the school of learning, whereas the concept of "competencebased competition" attaches secondary importance to a company's capabilities (Sanchez, Heene 2007).

The questioning of both the validity of isolating the concept of dynamic capabilities and of its assumptions is to a large extent the result of immaturity of the theoretical foundations and the problems related to the operationalization of the assumptions of dynamic capabilities. However, event the present stage of development of dynamic capabilities suggests significant progress in solving a number of methodological problems faced by the modern theory of strategic management. What seems particularly attractive about the concept of dynamic capabilities is the assumption that there is a need for a synthesis of the economic and behavioral aspects of company operations in the process of analyzing knowledge-management-related problems. It is noteworthy that the results of the most important research on knowledge management are consistent with the logic behind dynamic capabilities. This is especially true for "knowledge-creating companies" and intellectual capital management (Nonaka, Teece 2010, Rokita 2003).

\section{Summary}

\section{The Strategic Dimension of the Dynamic Capabilities of Enterprises}

The aim of this paper is to contribute to the debate on the concept of dynamic capabilities of enterprises and present of its principles from the perspective of strategic management. The paper starts with the presentation of importance of paradigms in strategic management. It is followed by the discussion of the concept of dynamic capabilities and of the strategic aspects of the concept of dynamic capabilities of enterprises. 
Keywords: Dynamic capabilities, strategic management.

\section{Streszczenie}

Strategiczny wymiar dynamicznych zdolności przedsiębiorstw

Celem artykułu jest włączenie w dyskusję nad koncepcją dynamicznych zdolności przedsiębiorstw i przedstawienie jej założeń z perspektywy zarządzania strategicznego. Punktem wyjścia w artykule uczyniono zarysowanie znaczenia paradygmatów w zarządzaniu strategicznym. Na tym tle przedstawiono koncepcję dynamicznych zdolności i omówiono strategiczne aspekty koncepcji dynamicznych zdolności przedsiębiorstw.

Słowa

kluczowe: Dynamiczne zdolności, zarządzanie strategiczne.

\section{References}

1. Collins, J. C., Porras, J. I. (2008), Wizjonerskie organizacje, MT Biznes, Warszawa.

2. Eisenhardt K. M., Martin J. A. (2010), Dynamic capabilities: What are they?, Strategic Management Journal, 21 (10-11), s.1105-1121.

3. Helfat, C. E., Peteraf, M. A. (2003), The dynamic resource - based view: Capability lifecycles.Strategic Management Journal 24 (10), s. 997-1010.

4. Nonaka I., Teece D. J. (eds.) (2010), Managing Industrial Knowledge. Sage Publications: London.

5. Porter M. E. (1991), Toward a dynamic theory of strategy. Strategic Management Journal 12, s. 95-117.

6. Porter, M. E. (1996), What is strategy? Harvard Business Review 74 (6), s. 61-78.

7. Rokita, J. (2003), Organizacja uczaca się, Wyd. AE w Katowicach, Katowice.

8. Rumelt, R. P. (1984), Towards a strategic theory of the firm. In: Lamb R. B. (ed.), Competitive Strategic Management. Prentice - Hall: Englewood Cliffs, NJ, s. 556-570.

9. Sanchez R., Heene A. (2007), Reinventig strategic management: New theory and practice for competence - based competition, European Management Journal 15 (3), s. 303-317.

10. Teece D. J. (2008), Dynamic capabilities.In: Lazonick W. (ed.), The international Encyclopedia of Business and Management. Thomas Learning Publishers, London, s. 1497-1512. 
11. .Volberda H. W. (2008), Strategic flexibility: Creating dynamic competitive advantage. In: Faulkner D. O., Campbell A. (eds.), The Oxford Handbook Strategy. Vol. 2: Corporate Strategy. Oxford University Press: N.Y., s. 447-465.

12. Volberda, H. W., Elfring, T. (eds.) (2010), Rethinking Strategy, Sage Publications: London.

13. Winter, S.G., (2003), Understanding dynamic capabilities, Strategic Management Journal 24 (10), s. 991-995.

14. Zollo M., Winter S.G., (2002), Deliberate learning and the evolution of dynamic capabilities, Organization Science 13 (3), s. 339-351.

15. Zott C. (2008), Dynamic capabilities and the emergence of intraindustry differential firm performance: Insights from a simulation study, Strategic Management Journal 24 (2), s. 97-125. 